\title{
Touch-and-go as an inclusive education strategy in case of visual impairment
}

DOI 10.26512/Ic.v25i0.23066

\author{
Adriano Bressane ${ }^{1}$ \\ Geraldo Eustáquio Moreira² \\ Sandra Bizarria Lopes Villanueva ${ }^{3}$
}

\section{Abstract}

The perceptual strength in learning styles refers to obtain knowledge most easily by different sensory systems. Discovering the perceptive strengths and weaknesses of each student and finding ways to optimize their learning is always a challenge for the professor. In extreme cases such as in the visual impairment touch-and-go approaches can be an alternative. This paper aims at sharing the usage of tactual resources as a learning strategy in a case of visual impairment, developed by a group of professors for supporting classes of Linear Algebra and Analytic Geometry at Sorocaba Engineering College (Faculdade de Engenharia de Sorocaba - FACENS). As a result, there was ease of handling tactile resources by the student, considerable gain in understanding the theoretical subjects and of practical cases analyzed in classroom. According to professors' perception, the concrete experimentation by using the touch-and-go strategy provided satisfactory support for the classes. Therefore, the usage of touch-and-go by means of the tactile resources can be considered as a promising approach as a learning strategy in cases of visual impairment.

Keywords: Learning strategy. Visual impairment. Hands-on. Linear Algebra.

1 Doutor em Ciências Ambientais pela Universidade Estadual Paulista - UNESP. Professor Assistente Doutor da Universidade Estadual Paulista UNESP, Campus de São José dos Campos (SP), adriano.bressane@unesp.br.

2 Doutor em Educação Matemática pela PUCSP, com Estágio Doutoral na Universidade do Minho/PT. Professor Adjunto da Universidade de Brasília - UnB. Pesquisador dos Programas de Pós-Graduação em Educação PPGE/UnB (Mestrado e Doutorado acadêmicos e Mestrado Profissional). Líder do Grupo de Pesquisa Dzeta Investigações em Educação Matemática - DIEM, geust2007@gmail.com.

3 Doutora em Engenharia Química pela UNICAMP. Professora Titular da Faculdade de Engenharia de Sorocaba - FACENS, sandra.lopes@facens.br. 


\section{Résumé}

La force perceptive dans les styles d'apprentissage se réfère à l'obtention de connaissances plus facilement par différents systèmes sensoriels. Découvrir les forces et les faiblesses perceptives de chaque élève et trouver des moyens d'améliorer son apprentissage est toujours un défi pour l'enseignant. Dans les cas extrêmes, tels que la basse vision, l'approche tactile peut être une alternative. Ce travail vise à partager l'expérience pédagogique de l'utilisation des ressources tactiques comme une stratégie d'apprentissage dans un cas de déficience visuelle, développé pour soutenir les classes en algèbre linéaire et géométrie analytique à Faculdade de Engenharia de Sorocaba (Facens). De ce fait, il a été facile de gérer les ressources tactiques de l'élève, de réaliser des progrès considérables dans la compréhension des concepts théoriques et des cas pratiques analysés en classe. Selon les perceptions des enseignants, l'expérimentation concrète à l'aide d'une stratégie tactile (touch-and-go) a fourni un soutien satisfaisant aux cours. Par conséquent, l'approche tactile peut être considérée comme une stratégie prometteuse en cas de déficience visuelle.

Mots-clés: Stratégie d'apprentissage. Déficience visuelle. Les mains dans la pâte. Algèbre linéaire.

\section{Resumen}

La fuerza perceptual en los estilos de aprendizaje se refiere a obtener conocimiento más fácilmente por diferentes sistemas sensoriales. Descubrir las fuerzas y debilidades perceptivas de cada alumno y encontrar maneras de mejorar su aprendizaje es siempre un desafío para el profesor. En casos extremos, como los de baja visión, el enfoque touch-and-go puede ser una alternativa. Este trabajo tiene por objetivo compartir la experiencia pedagógica del uso de recursos táticos como estrategia de aprendizaje en un caso de deficiencia visual, desarrollada para apoyar clases de Álgebra Lineal y Geometría Analítica en la Facultad de Ingeniería de Sorocaba (Facens). Como resultado, se verificó facilidad en el manejo de los recursos táticos por el alumno, ganancia considerable en la comprensión de los conceptos teóricos y de los casos prácticos analizados en el aula. De acuerdo con la percepción docente, la experimentación concreta usando la estrategia basada en recursos táctiles (touchand-go) proporcionó apoyo satisfactorio para las clases. Por lo tanto, el enfoque touchand-go puede ser considerado una estrategia prometedora en casos de deficiencia visual.

Palabras clave: Estrategias de aprendizaje. Deficiencia visual. Manos en la masa. Álgebra lineal. 


\section{Resumo}

A força perceptual nos estilos de aprendizagem refere-se a obter conhecimento mais facilmente por diferentes sistemas sensoriais. Descobrir as forças e fraquezas perceptivas de cada aluno e encontrar maneiras de melhorar sua aprendizagem é sempre um desafio para o professor. Em casos extremos, como os de baixa visão, a abordagem touch-and-go pode ser uma alternativa. Este trabalho tem por objetivo compartilhar a experiência pedagógica do uso de recursos táticos como estratégia de aprendizagem em um caso de deficiência visual, desenvolvida para apoiar aulas de Álgebra Linear e Geometria Analítica na Faculdade de Engenharia de Sorocaba (Facens). Como resultado, verificou-se facilidade no manejo dos recursos táticos pelo aluno, ganho considerável na compreensão dos conceitos teóricos e dos casos práticos analisados em sala de aula. De acordo com a percepção docente, a experimentação concreta usando a estratégia baseada em recursos táteis (touch-and-go) proporcionou apoio satisfatório para as aulas. Portanto, a abordagem touch-and-go pode ser considerada uma estratégia promissora em casos de deficiência visual.

Palavras-chave: Estratégia de aprendizagem. Deficiência visual. Mãos na massa. Álgebra Linear.

\section{Introduction}

Teaching-learning processes have always existed as a natural process resulting from different forms of social interaction, from simple observation by the most rudimentary animals until those by means of the most sophisticated man-made technological tools (BRESSANE; RIBEIRO; MEDEIROS, 2015, 39p.).

The perceptual strength in learning styles refers to obtain practical and theoretical knowledge most easily by hearing, seeing, verbalizing, or actively experiencing. Naturally, the learning process results from a combination of different sensory and mental abilities, but according to the biological characteristics of each individual some of them can be more effective than others (Rogowsky \& Calhoun; Tallal, 2015).

Discovering the perceptual strengths and weaknesses of each student and finding ways to optimize their learning is always a challenge for the professor. In extreme cases, mental and physical impairments may partially or totally affect a particular sensory ability, as occurs in cases of visual impairment, in which touch-and-go approaches, i.e, teaching and learning with tactual resources can be an alternative in replacing the visual perception (Galassi \& Akos, 2017; Camargo, 2010; Mantoan, 1997).

Some experiences have been reported in the literature (Xavier, 2018; Sobral et al., 
2017; Maravalhas \& Bastos 2015; FONTES; Cardoso \& Ramos, 2012; Camargo, 2010; Camargo, Nardi \& Veraszto, 2008; Costa, Neves \& Barone, 2006; Moreira, 2014, 2015, 2016; Moreira \& Manrique, 2014a, 2014b).

Moreira (2014, 2015, 2016a, 2016b) they have been working with materials, methods, activities and teacher training that teach mathematics to students with special educational needs (SEN). According to the researcher, the inclusion of schoolchildren with deficiencies has had important repercussions in the most different levels of organization of the world's educational systems, with a strong growth in Brazil in the last decades. In communion with their work, it can be seen that there are few studies related to the inclusion of students with SEN in mathematics classes, which makes the field of research rich and in need of research that bring a look at the diversity of the Mathematics classroom.

This diversity of views on what still needs to be exhaustively studied, which lacks the better pedagogical work conditions of the student with SEN, has been presented in some investigations. Camargo (2010) analyzes the communication difficulties between professors and students with visual impairment. In conclusion, the author emphasizes the importance of creating adequate communication channels as a basic condition for the inclusion of these students.

Maravalhas and Bastos (2015) pointed out the use of inclusive tools and resources as an alternative to overcome barriers and enable autonomy of students with visual impairment. In this sense, Xavier (2018) highlights mathematics as a component of great visual character, and describes the use of a hand-held calculator adapted for visually impaired students.

Fontes, Cardoso and Ramos (2012) share an experience on the teaching-learning process of graphics in physics classes. Such authors describe the use of the 'multiplane'; an educational kit specialized for tactile perception, as a substitutive alternative to visual perception with satisfactory results. Sobral et al. (2017) describe the use of Role Playing Digital Games as a tool for learning the visually impaired.

Moreira and Manrique (2014a) highlight that "collectivity is able to transfer knowledge that would not be possible in social isolation" (p. 472). What these researchers have been saying is that we need to insert the student with SEN in all classes, especially in Mathematics, since one of the biggest problems related to inclusion lies in the postures adopted by teachers of the exact ones.

In contrast to the gradual advances cited above, it is observed that the thinking and the action in the schools in relation to Mathematics, often, consider the students, both so-called "normal" and those with some SEN (Moreira, 2014, 2015, 2016a, 2016b). It is disregarded how students with SEN need to be involved in interventions, especially in relation to higher psychological functions, mental processes and the formation of mathematical concepts. What we have in reality, many times, are teachers who do not 
know very well how to include these students, mainly due to the reflection of a weak and weak formation that needs to be rethought from the point of view of the diversity present in the classes of Mathematics (Moreira, 2016a, 2016b; Sandes \& Moreira, 2018). Despite these examples, there is still a few number of outcomes reported in the literature on the inclusive teaching-learning of visually impaired students (Fontes, Cardoso \& Ramos, 2012; Moreira, 2014, 2015, 2016a, 2016b). Therefore, the present paper aims to share a touch-and-go approach as a learning strategy in a case of visual impairment, developed by a group of professors for supporting classes of Linear Algebra and Analytic Geometry in Sorocaba Engineering School (Faculdade de Engenharia de Sorocaba - FACENS). More narrowly, we intend to discuss the inclusion / mathematics dyad; to present successful experiences on the inclusion of students with SEN in Mathematics classes and also to demonstrate the contributions that the use of didactic resources has in the teaching and learning process of Mathematics for students with visual impairment.

\section{Teaching-learning strategy in case of visual impairment}

The teaching-learning strategy addressed in this paper is based on two set of touch-and-go resources. The first one corresponds to tactile resources built by professors of FACENS, using low-cost materials. In turn, an educational kit specialized for tactile perception has been also used during the classes, as described ahead.

The discussion about inclusion in mathematics classes and the relation between teaching and learning are essential in this scenario and will be anchored in the discussion about the production of materials, technologies and strategies to assist in the organization of mathematical reasoning, since they contribute greatly to the discussion and expansion of the pedagogical action by arguing that students with SEN deserve to have school attendance based on social, pedagogical and cultural interactions, as well as the conception that learning generates development.

Currently, as people with disabilities are coming out of invisibility, under the auspices of Human Rights and the legal provisions that ensure social inclusion in all areas of life, these examples of overcoming are increasing, always in direct relation to the conditions of accessibility, with the reception in the social spaces and, fundamentally, with the awareness of all towards the right to diversity and human differences (Alves, 2015, p. 90).

According Moreira et al. (2016, p. 83), "quando se investigam ou dialogam sobre a inclusão de alunos com necessidades educativas especiais (NEE) em classes regulares" it is necessary "to develop innovative strategies and methodologies that support the 
school units so that they can meet the requirements of all students with and without SEN in all their specifics".

In this sense, tactile resources can be understood as assistance technologies or support to learning, since they involve pedagogical resources. According to Sartoretto and Bersch (2019), resources include any equipment, or part of it, a manufactured product or system used to increase, maintain, or improve the functional capabilities of persons with disabilities.

If "student training should have as its main objective and acquisition of basic knowledge, [...] to use the different technologies related to the areas of activity, [...]the ability to learn, create, formulate, rather than the simple exercise of memorization" (Secretaria de Educação Fundamental [SEF], 1998, p. 5), must be a recurring element in the classroom, since the technologies are pedagogical tools and mechanisms increasingly available to school environments, mainly available to specific knowledge areas for the active participation of students with SEN.

Therefore, the use of tactile resources in mathematics classes opens a range of possibilities for intervention and action with students in general, as it allows the prospective look, that is, even if the student has limitations due to his special needs, to do development and learning, which is one of the central objectives of education.

\section{Tactile resources built using low-cost materials}

When we refer to the various types of resources for working with SEN learners, we need to keep in mind all kinds of instruments that can minimize impacts. These instruments refer to Assistive Technology (AT), which can be products, equipment, devices, resources, methodologies, strategies, practices and services that aim to promote autonomy, independence, quality of life and social inclusion of persons with disabilities (Secretaria Nacional de Promoção dos Direitos da Pessoa com Deficiência [SNPD], 2008).

The AT presents a humanistic potential of social value in the face of possible mismatches in the learning rhythm (as a process that is plural, complex and multiple of sense), since it can aid and create stimuli to the capacity of perception, language and ontological understanding, since articulates different forms of being together and a multiplicity of knowledge. It is about claiming the right of social recognition in the experience with socially validated AT, which has repercussions on all dimensions of life, as a means by which people share their experiences and learn from each other, that is, it is an exercise in citizenship and cultural experience. (Conte, Ourique \& Basegio, 2017, p. 13).

Low-cost materials used in the construction of tactile resources included a wood 
sanding paper (Figure 1a), wire structure coated by a cloth woven together (Figure 1b), wooden sticks and a stylus (Figure 1c). The woven wireframe structure was employed for providing the tactile perception of a Cartesian plane in the representation and operations with vectors.

We consider that "an inclusive school is thus a school where every child is respected and encouraged to learn to the limit of his abilities" (Correia, 2008, p. 7), which can be done through the use of adequate and well thought-out assistive technology resources, based on the pedagogical presuppositions of inclusion of people with SEN in mathematics classes.

Figure 1. Materials used in the composition of the tactile resource.

$a$

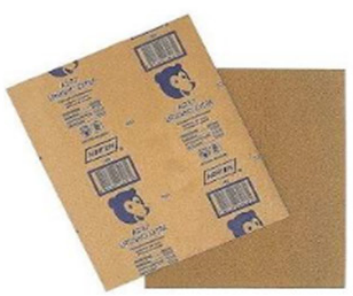

b

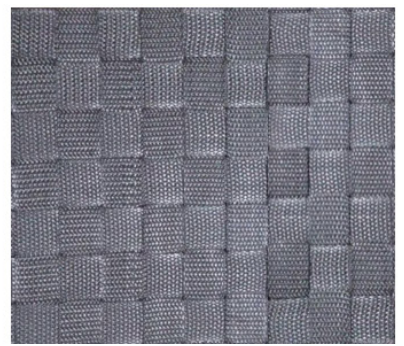

C

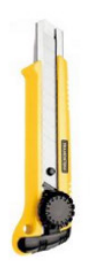

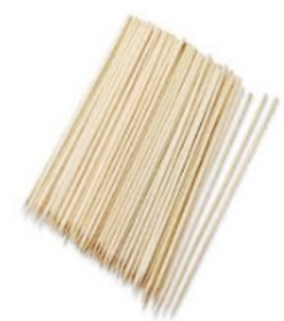

Source: produced by the authors.

The strong tactile appeal was a pedagogical strategy because

I cannot be a teacher if I do not perceive more and better that, because I cannot be neutral, my practice demands of me a definition, a positioning. Decision. Break. It requires me to choose between this and that. I cannot be a teacher and simply make of Man or Humanity, a vague phrase too much contrast with the concreteness of educational practice (Freire, 1996a, p. 115).

The texture of the wire structure coated by a cloth woven together, highlighted in Figure 2, sought to simulate the partitions of the orthogonal decomposition bases $(x O y)$, as well as the pairs of Cartesian points $(x, y)$ formed at the intersections of these partitions. 
Figure 3. Tactile Simulation of the Cartesian plane with the wire structure coated by a cloth woven together.
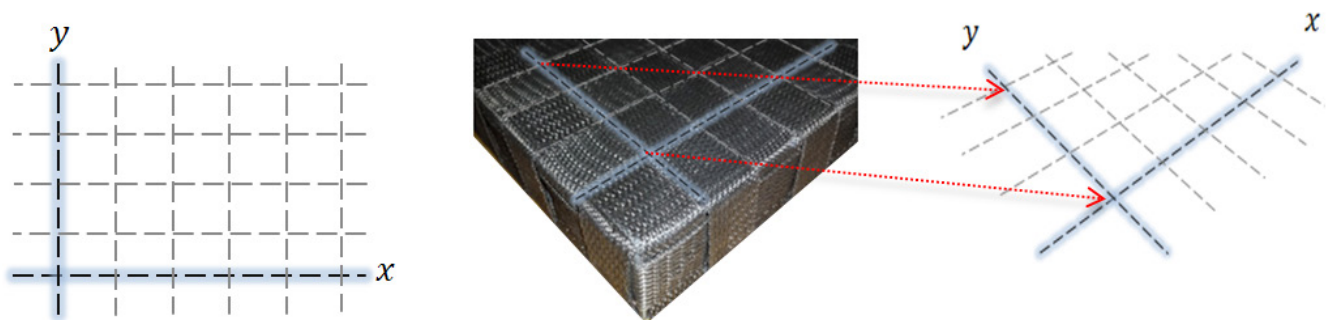

Source: produced by the authors.

Figure 2 refers to the thought of Kensk (2015). For her, in any discipline, for any teacher or any student, it is possible to make use of new technologies to teach and learn, both collectively and individually.

New communication technologies (ICTs) have driven education and brought new mediations between approach, understanding and content. The image, the sound and the movement offer more realistic information regarding what is being taught. When well used, they provoke the alteration of the behaviors of teachers and students, leading them to better knowledge and to deepen the studied content (Kensk, 2015, p. 45).

The student's handling of the wooden sticks sought the tactile perception of the representation of the vector as a straight line, as well as working the concept of a module associated with the length of these sticks (Figure 3a).

Figure 3. Tactile simulation of the vector with wooden sticks.
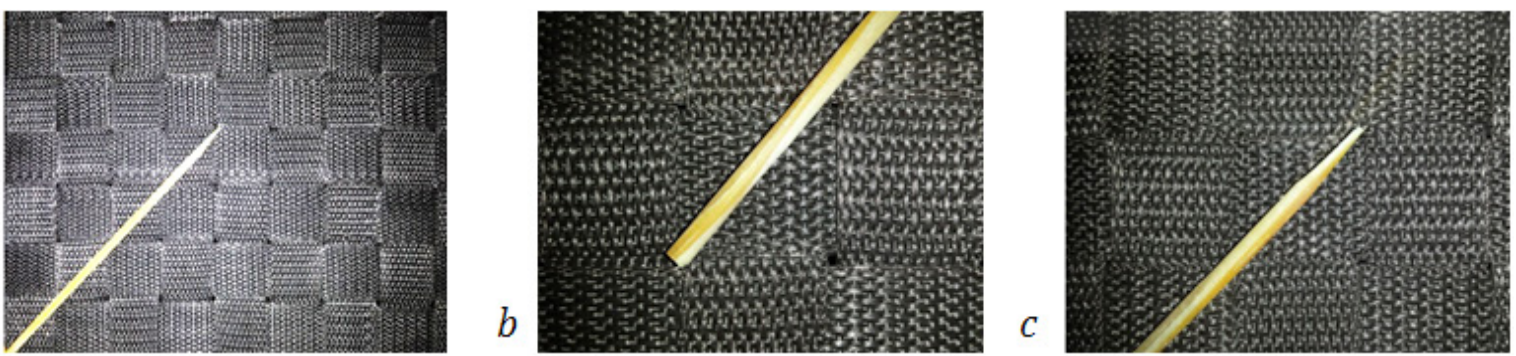

Source: produced by the authors.

Maintaining the straight stick shape at one of its tips allowed us to work on the vector origin concept (Figure $3 \mathrm{~b}$ ). In turn, the use of the stylus and the sandpaper made it possible to accentuate the thinning of the other end of the stick and, in this way enhancing the tactile perception of the extremity and to work the concept of direction (vector orientation). 
Consistently, Moreira (2016a, p. 752) believes that

It is important that teachers who teach mathematics have at their disposal instructional, instructional, appropriate and quality materials, [...] leading students to construct mathematical concepts, either through the use of didactic games or through play activities to mobilize all students in the classroom towards effective mathematical learning.

As a result from the usage of touch-and-go resources during the classes, the structure coated by a cloth woven together and the wooden sticks allowed to work the tactile perception of the geometrical methods and operation with vectors (Figure 4a), both in the 2D-plane (Figure 4b) and in 3D-space (Figure 4c).

Figure 4. Usage of touch-and-go resources for tactile perception in 2D-plane (a) and 3D-space (b, c).

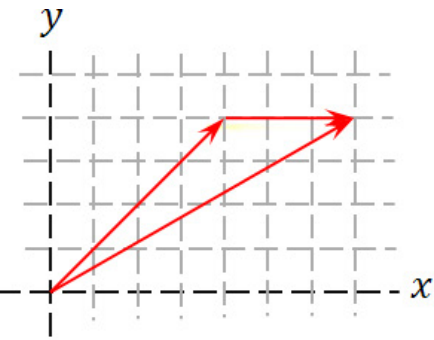

$b$

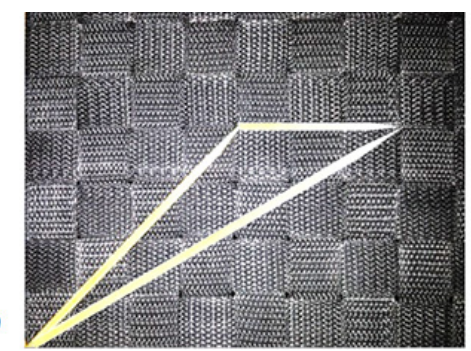

$c$

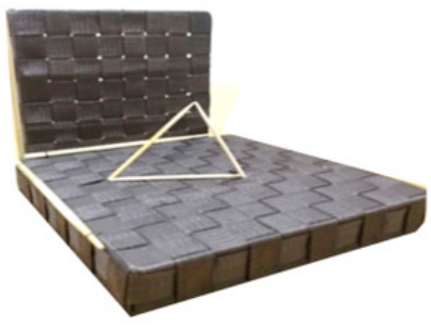

Source: produced by the authors.

The usage in class of the resources described gave quite satisfactory results. By consulting the visually impaired student at the end of the classes, s/he reported ease of resource handling and considerable gain in understanding the concepts and operations worked in the classroom (Figure 5).

Figure 5 . Use of tactile perception resources in the classroom by the visually impaired student. 

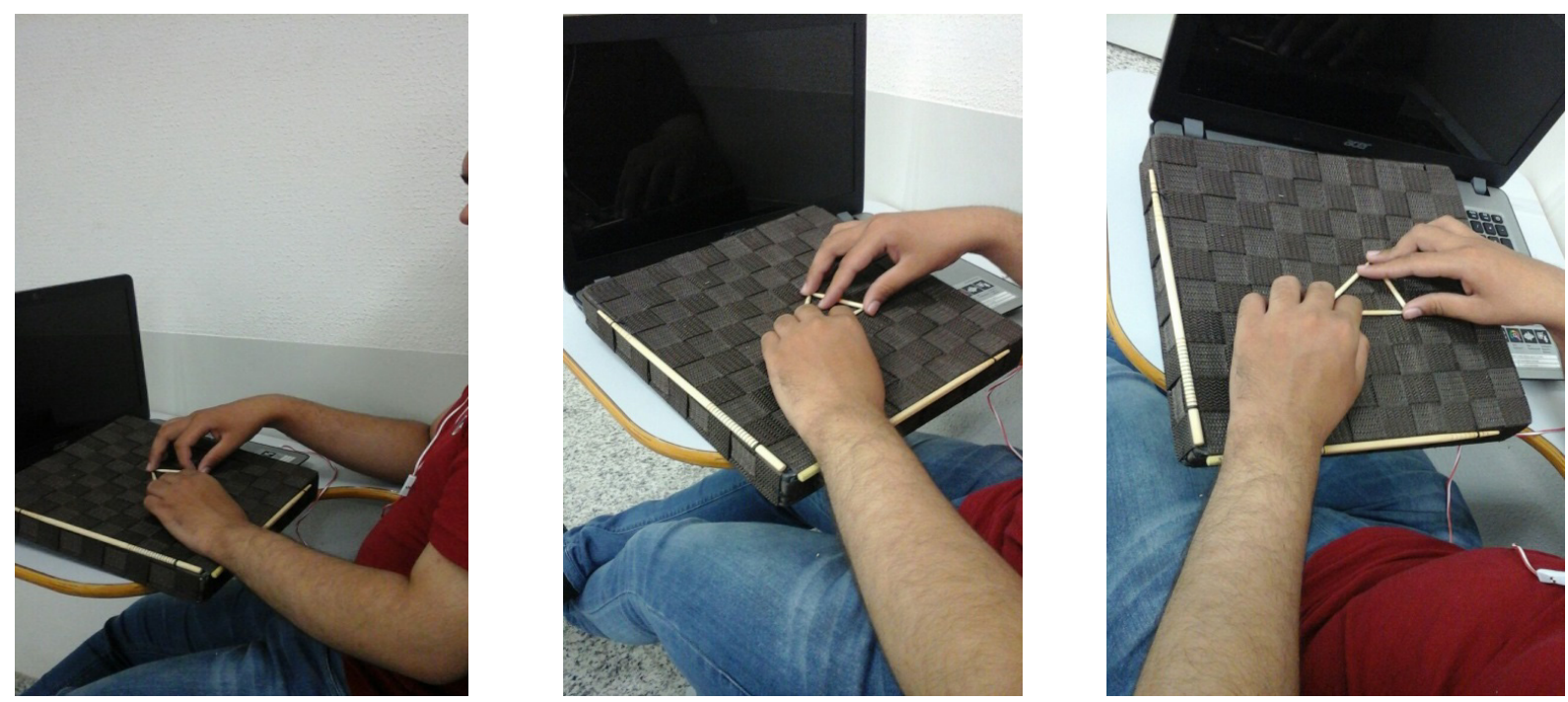

Source: produced by the authors.

Similarly, Moreira (2014) has been insisting that, from a practical class in which mathematical knowledge is brought into the everyday life of students, they present "better learning conditions, retention of content, and develop other skills" (p. 47), whether at the level of language or at the level of mathematics.

\section{Educational kit specialized for tactile perception}

In th mid-2000's, the Multiplane Classroom Kit was developed by professor Rubens Ferronato, who was facing difficulties in teaching math to a blind student. Since then, this kit has been upgraded and traded for educational purposes, especially for concrete experimentation of theoretical concepts (Figure 6).

Figure 6. Commercial multiplane classroom kit. 

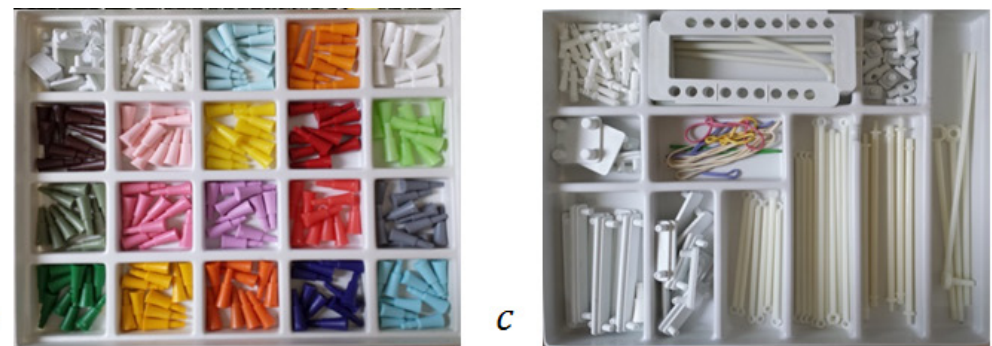

Source: produced by the authors.

The commercial kit includes a perforated plate, which can be used as Cartesian plane (Figure 6a), a set of pieces to construct geometric elements (Figure 6b) and graphical representations (Figure 6c). As represented in Figure 7, these components allow the tactile perception of the vector, as well as of geometric operations. To standardize the use of the kit, the professors defined specific pieces to represent the origin (Figure 7a) and the extremity (Figure $7 \mathrm{~b}$ ) of vectors hence supporting the concrete experimentation of vector direction and orientation.

Wisely, the teacher understood that "the hand of the blind is the extension of his vision, hence the touch has a special meaning in its autonomy and independence", because in this case, it is the school and the teacher to stimulate "this tactile sense, creating an environment that can develop the spatial notion " (Coimbra, 2003, p. 223).

Figure 7. Tactile simulation of the vector with pieces from multiplane classroom kit.
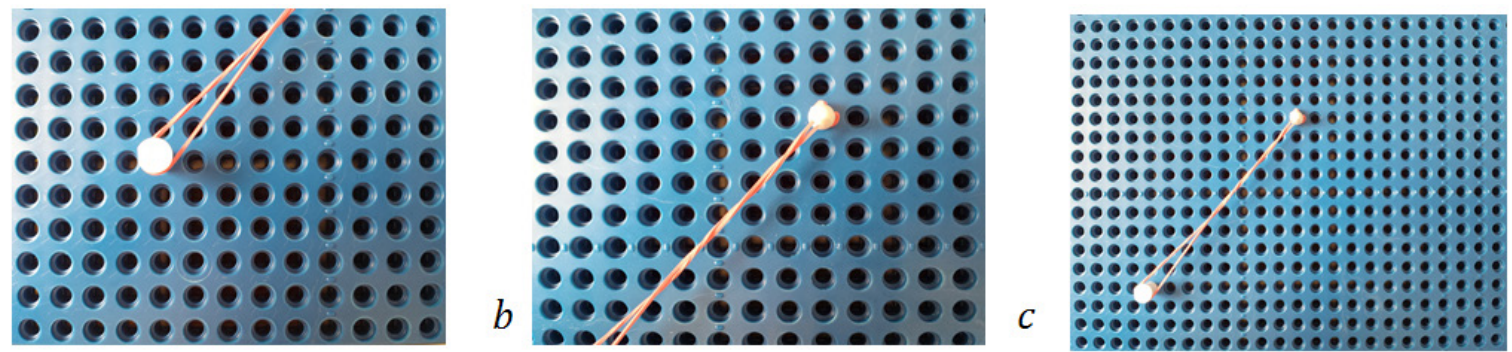

Source: produced by the authors.

It is evident that the incessant search to attend the visually impaired students, in this specific activity, makes the teacher a true researcher of his practice (Moreira, 2014, 2015, 2016a). Because,

What is a researcher in the teacher is not a quality or a way of being or acting that is added to that of teaching. It is part of the nature of the teaching practice the inquiry, the search, the research. What is needed is that, in its permanent formation, the teacher 
perceives and assumes, because teacher, as researcher (Freire, 1996b, p. 29).

Then rubber bands were used for connecting such pieces and, this way, providing the tactile perception of vector module (Figure c). Prior to use by the blind student, a monitor prepared the multiplane (Figure 8a) representing the cases under analysis (Figure 8b). It can be seen in Figure 8 that the axes of orthogonal basis were represented by a double line, to differentiate such axes from vectors.

Figure 8. Usage of multiplane classroom kit for tactile perception of cases under analysis.
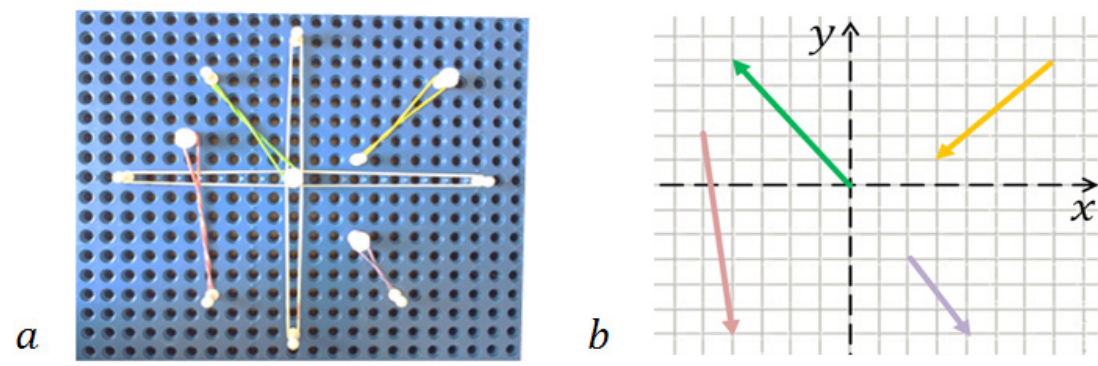

Source: produced by the authors.

It can be seen in Figure 8 that the axes of orthogonal basis were represented by a double line, to differentiate such axes from vectors. As a result from usage of multiplane kit in the classroom, the student reported ease of handling and satisfactory understanding the cases under analysis (Figure 9).

Figure 9. Usage of multiplane classroom kit in the classroom by the visually impaired student.
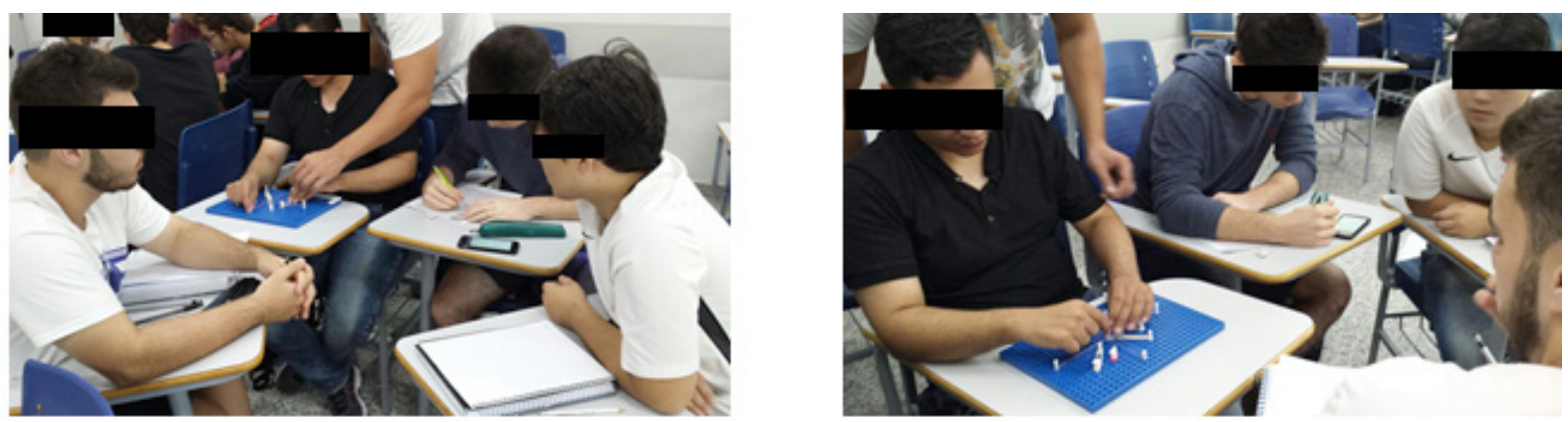

Source: produced by the authors.

We have observed that the light and inefficient teacher training that teaches Mathematics does not take care of attending all students, especially those with atypical development (Moreira, 2014, 2015, 2016a, 2016b). Thus, ideas related to exclusion reinforce stereotypes and attitudes by reference to a homogeneous "standard student", participant in a heterogeneous classroom: 
As a result, many teachers entering the profession with these stereotyped views take quite some time to undo them. Others never exceed them, carrying out a practice that ends up contributing to the production of the huge contingent of those excluded from and in school (Freitas, 2006, p. 170).

Finally, it should be said that the history of teachers who seek to improve the teaching and learning of students with disabilities is directly influenced by the teaching profession, because these teachers, in a brutal effort to internalize knowledge, skills, beliefs and values that structure and shape their personalities, make relations with the other more equanimous from the point of view of acceptance and experiences of the practices themselves (Tardif, 2010).

\section{Final considerations}

The present paper aimed at sharing an experience of the use of activities based on tactile resources, as a teaching-learning strategy in case of visual impairment, developed to support classes of Linear Algebra and Analytical Geometry, discussing the inclusion / mathematic dyad. Moreover, we demonstrate the contributions that the use of didactic resources has in the teaching and learning process of mathematics for students with SEN, especially for those with visual impairment and / or blindness.

In addition to presenting different materials constructed by ourselves, we have evoked different researchers who have been working with issues related to inclusion in mathematics classes, which has allowed a rich and possible debate in the face of the difficulties found in schools and colleges (Camargo, 2010; Coimbra, 2003; Correia, 2008; Freitas, 2006; Mantoan, 1997; Moreira, 2014, 2015, 2016a, 2016b; Xavier, 2018).

Allied to these questions, we have brought information related to the use of assistive technologies in Mathematics classes, which were also discussed, being anchored in renowned researchers who affirm that these technologies can contribute significantly to the improvement of the teaching and learning process of Mathematics, besides the indispensability of its use when working with apprentices with visual impairment, as is the case (Conte, Ourique \& Basegio, 2007; Fontes, Cardoso \& Ramos, 2012; Kensk, 2015; Maravalhas \& Bastos, 2015; Sartoretto \& Bersch, 2018).

Fortunately, it is well known that classes in Linear Algebra and Analytical Geometry rely on visual resources such as graphical representations and geometric methods developed on the Cartesian plane. This approach is widely used and generally delivers good results to students. However, traditional methodologies may not be appropriate in cases of visual impairment, requiring approaches that provide an inclusive education, as signaled by us. 
From the outcomes reported in this paper, it can be concluded that the usage of touchand-go by means of the tactile resources built by professors, as well as using the commercial multiplane classroom kit, represents a promising approach as a learning strategy in cases of visual impairment.

It is obvious to us that "[...] the research in Brazil is past the time when it proclaimed only in general: "We have to generate a reflective teacher", giving a great leap "to a stage in which already presents more elaborate discussions that are at the same time the fruit and seed of new questions" about the new knowledge necessary to the teachers who teach Mathematics (Borba, 2006, p. 13).

According the visually impaired student, there was ease of handling tactile resources, considerable gain in understanding the theoretical subjects and of cases analyzed in classroom. In the perception of professor, the concrete experimentation by using the touch-and-go strategy provided satisfactory support for approaching the course contents of Linear Algebra and Analytic Geometry. Therefore, the authors recommend the use of this approach for similar cases.

\section{Acknowledgment}

The authors thank the whole team of the Faculdade de Engenharia de Sorocaba, for the broad support in the developing of the approach herein described. They also thank the Universidade de Brasília - UnB and to Fundação de Apoio à Pesquisa do Distrito Federal - FAPDF, for the support and encouragement of the Research Project "Teacher training of Mathematics in the Field Education Perspective: teacher training and practice, specific Mathematics didactics and follow-up of student learning" 


\section{References}

Bressane, A., Ribeiro, A. I., \& Medeiros, G. A. (2015). Problematização como estratégia interdisciplinar: uma experiência na Pós-graduação em Ciências Ambientais. In Soares, S. R., Martins, E. S., \& Miranda, D. L. (Orgs.). Problematização e produção criativa: ressignificando o ensino e a aprendizagem na universidade Salvador/BA: DUFOP.

Borba, M. C. (2006). Diversidade de questões em formação de professores de matemática. In Borba, M. C. Tendências internacionais em formação de professores de matemática. Belo Horizonte, MG: Autêntica.

Camargo, E. P. (2010). A comunicação como barreira à inclusão de alunos com deficiência visual em aulas de mecânica. Ciência \& Educação, vol. 16, n. 1, pp. 259275.

Camargo, E. P., Nardi, R., \& Veraszto, E. V. (2008). A comunicação como barreira à inclusão de alunos com deficiência visual em aulas de óptica. Revista Brasileira de Ensino de Física, vol. 30, n. 3, pp. 3401-3414.

Coimbra, I. D. (2003). A Inclusão do portador de deficiência visual na escola regular. Salvador: EDUBRA.

Conte, E., Ourique, M. L. H., \& Basegio, A. C. (2017). Tecnologia Assistiva, Direitos Humanos e Educação Inclusiva: uma nova sensibilidade. EDUR - Educação em Revista, Belo Horizonte (MG), v. 33, e163600. Disponível em http://www.scielo. $\mathrm{br} / \mathrm{pdf} / \mathrm{edur} / \mathrm{v33} / 1982-6621$-edur-33-e163600.pdf.

Correia, L. M. (2008). Inclusão e necessidades educativas especiais. Um guia para educadores e professores. 2. ed. Porto: Porto Editora.

Costa, L. G., Neves, M. C. D., \& Barone, D. A. C. (2006). O ensino de Física para deficientes visuais a partir de uma perspectiva fenomenológica. Ciência \& Educação, vol. 12, n. 2, pp. 143-153.

Fontes, A. S., Cardoso, F. A. R., \& Ramos, F. V. (2012). Como trabalhar gráficos com aluno deficiente visual - Relato de experiência. Revista Thema, vol. 9, n. 1, pp. 1-13.

Freire, P. (1996a). Pedagogia da Autonomia: saberes necessários à prática educativa. 5. Ed. Rio de Janeiro: Paz e Terra.

Freire, P. (1996b). Pedagogia da Autonomia. São Paulo: Paz e Terra. 
Freitas, S. N. Freire, P. (2006). Formação de professores na educação inclusiva. In: Rodrigues, D. (org). Inclusão e Educação: doze olhares sobre a educação inclusiva. São Paulo: Summus Editorial.

Galassi, J. P., \& Akos, P. (2017). Strengths-Based School Counseling: Promoting Student Development and Achievement. New York: Routledge.

Kensk, V. M. (2015). Educação e tecnologias: O novo ritmo da informação. Campinas, SP: Papirus.

Mantoan, M. T. E. (1997). A Integração de pessoas com deficiência: contribuições para uma reflexão sobre o tema. São Paulo: Editora SENAC.

Maravalhas, M. R. G., \& Bastos, M. O. (2015). Os benefícios das tecnologias assistivas para a aprendizagem e desenvolvimento educacional de alunos com deficiência visual. Revista de estudos em Linguagens e Tecnologia, vol. 11, n. 2, pp. 1-11.

Moreira, G. E. (2014). Resolvendo problemas com alunos com Transtornos Globais do Desenvolvimento: desafios e conquistas. Educação Matemática em Revista-RS, v. 01, pp. 38-48. Disponível em: http://sbemrs.org/revista/index.php/2011_1/article/ view/106

Moreira, G. E. (2015). A Educação Matemática Inclusiva no contexto da Pátria Educadora e do novo PNE: Reflexões no âmbito do GD7. Educação Matemática Pesquisa (Online), v. 17, pp. 508-519. Disponível em: https://revistas.pucsp.br/ index.php/emp/article/view/25667

Moreira, G. E. (2016a). O ensino de Matemática para alunos surdos: dentro e fora do texto em contexto. Educação Matemática Pesquisa, v. 18, pp. 741-757. Disponível em: https://revistas.pucsp.br/index.php/emp/article/view/23486

Moreira, G. E. (2016b). Os desafios da Educação Matemática Inclusiva no Programa de Pós-Graduação em Educação Matemática da PUCSP: As conquistas do OBEDUC. In Manrique, A. L., Maranhão, M. C. S. de A., \& Moreira, G. E. Desafios da Educação Matemática Inclusiva: Formação de Professores. Volume I. São Paulo: Editora Livraria da Física.

Moreira, G. E., \& Manrique, A. L. (2014a). Challenges in Inclusive Mathematics Education: Representations by Professionals Who Teach Mathematics to Students with Disabilities. Creative Education, v. 05, pp. 470-483. Disponível em:

http://file.scirp.org/Html/4-6302032_45390.htm 
Moreira, G. E., \& Manrique, A. L. (2014b). Educação Inclusiva: Representações Sociais de professores que ensinam Matemática. Poíesis Pedagógica, v. 12, pp. 127149. Disponível em: https://www.revistas.ufg.br/poiesis/article/view/31213

Moreira, G. E., \& Salla, H. (2018). O Atendimento Pedagógico Domiciliar de alunos que não podem frequentar fisicamente a escola por motivos de saúde: Revisão Sistemática das investigações realizadas entre 2002 e 2015. Revista Educação Especial, vol. 31, n. 60, pp. 119-138, jan./març. Disponível em: https://periodicos. ufsm.br/educacaoespecial/article/view/26680

Moreira, G. E., Manrique, A. L., Martins, A. P. L., Santos, A. C. dos, HattumJanssen, N. V., Arezes, P. M. F. M., \& Martinho, M. H. (2016). Validação da Escala Multidimensional de Inclusão de Alunos com NEE em Aulas de Matemática. In Manrique, A. L., Maranhão, M. C. S. de A., \& Moreira, G. E. Desafios da Educação Matemática Inclusiva: Formação de Professores. Volume I. São Paulo: Editora Livraria da Física.

Rogowsky, B. A., Calhoun, B. M., \& Tallal, P. (2015). Matching Learning Style to Instructional Method: Effects on Comprehension. Journal of Educational Psychology, vol. 107; n. 1, pp. 64-78.

Sandes, J. P., \& Moreira, G. E. (2018). Educação Matemática e a Formação de Professores para uma prática docente significativa. Revista @mbienteeducação, v. 11, pp. 99-109. Disponível em: http://publicacoes.unicid.edu.br/index.php/ ambienteeducacao/article/view/49

Sartoretto, M. L., \& Bersch, R. (2017). O que é Tecnologia Assistiva? Assistiva: Tecnologia e Educação. Disponível em: http://www.assistiva.com.br/tassistiva. html\#porque. Acesso em: 13 jan. 2018.

Secretaria de Educação Fundamental [SEF]. (1998). Parâmetros Curriculares Nacionais: Matemática. Brasília: MEC/SEF.

Secretaria Nacional de Promoção dos Direitos da Pessoa com Deficiência [SNPD]. (2008). Tecnologia Assistiva. Disponível em: http://www.pessoacomdeficiencia.gov. br/app/publicacoes/tecnologia-assistiva

Sobral, F., Umeres, L., Schanoski, W., Bartelmebs, R., \& Assis, M. (2017). A Utilização de Role Playing Games Digitais como Ferramenta Complementar no Processo de Aprendizagem de Crianças Deficientes Visuais. Simpósio Brasileiro de Informática na Educação, Anais..., Pernambuco, Recife.

Tardif, M. (2010). Saberes docentes e Formação Profissional. 11ª edição, Editora Vozes, Petrópolis, Rio de janeiro. 
Xavier, T. M. A. M. (2018). Educação inclusiva: O uso do Soroban no processo da aprendizagem matemática para deficientes visuais. Trabalho de Conclusão de Curso (Graduação em Matemática) - Universidade Estadual da Paraíba, Campina Grande. 